\title{
The effect of dietary energy concentration on the hormone profile and lipid metabolism in growing pigs
}

\author{
E. Sawosz ${ }^{1,4}$, A. Chwalibog ${ }^{2}$, J. Skomial ${ }^{1}$, I. Kosieradzka ${ }^{1}$ \\ and A.J. Zięcik ${ }^{3}$ \\ ${ }^{1}$ Warsaw Agricultural University, Department of Animal Nutrition and Feed Science \\ Ciszewskiego 8, 02-786 Warsaw, Poland \\ ${ }^{2}$ Department of Animal and Veterinary Basic Sciences, \\ The Royal Veterinary and Agricultural University \\ Bülowsvej 13, 1870 Frederiksberg C, Denmark \\ ${ }^{3}$ Institute of Animal Reproduction and Food Research, Polish Academy of Sciences \\ Tuwima 10,10-747 Olsztyn, Poland
}

\section{ABSTRACT}

Growing pigs, as a model for humans, $(2$ groups $\times 7)$ were fed diets with high or low levels of energy and protein. The diet low in energy and protein decreased insulin, leptin, thyroxin levels but did not decrease concentrations of glucose, triacylglycerols or cholesterol. A reduced supply of energy and protein can decrease the levels of anabolic hormones in a growing organism.

KEY WORDS: pigs, feeding level, energy concentration, lipids, insulin, leptin

\section{INTRODUCTION}

The life span of animals and humans can be increased by energy restriction operating via decreasing the metabolic rate and reduction in body fat content. The quantity and quality of body fat regulates the metabolism of fatty acids, which determines expression of genes encoding the enzymes involved in the $\beta$-oxidation of fatty acids, lipoprotein and hormone-dependent lipolysis, synthesis of cholesterol, as well as proliferation of thyroid gland cells and secretion of triiodothyronine $\left(\mathrm{T}_{3}\right)$ (Raclot and Oudart, 1999). Food restriction modifies the endocrine and nervous system, influencing the metabolism of the entire organism. However, a suf-

\footnotetext{
${ }^{4}$ Corresponding author: e-mail: sawosz@alpha.sggw.waw.pl
} 
ficient energy supply is necessary for ATP synthesis required for optimal growth and development. The question is to what extent the pro-aging dietary effects decrease genetically defined capacities for growth and development and whether increasing the life span of an adult requires a reduced rate of growth and development of a young organism.

The aim of this study was to evaluate the influence of high and low energy and protein supply on the level of selected anabolic hormones and indices of lipidcarbohydrate metabolism in growing pigs as a model for humans.

\section{MATERIAL AND METHODS}

Pigs (Landrace $\times$ White Large, $30 \mathrm{~kg}$ body weight) were divided into two groups $(2 \times 7$ animals $)$ and housed in individual cages for 100 days. The pigs were fed ad libitum with diets with high (H) and low (L) energy and protein concentrations (Table 1). At the end of the experiment the animals were fasted for $12 \mathrm{~h}$ and blood was sampled from the heart. Triacylglycerols (TG), total

Table 1. Composition and nutritional value of the experimental diets, $\%$

\begin{tabular}{lcc}
\hline & $\mathrm{L}$ & $\mathrm{H}$ \\
\hline Barley & 69.3 & 63.9 \\
Lucerne meal & 30.0 & - \\
Wheat & - & 10.0 \\
Soyabean meal & - & 13.5 \\
Meat-and-bone meal & - & 5.0 \\
Lard & - & 7.0 \\
Premix & 0.50 & 0.50 \\
L-Lysine & 0.22 & 0.12 \\
DL-Methionine & 0.017 & 0.018 \\
Metabolizable energy, MJ/kg & 9.52 & 13.5 \\
Crude protein & 12.6 & 17.7 \\
Lysine & 0.66 & 0.94 \\
Methionine & 0.41 & 0.58 \\
Rate protein:energy & $13.2: 1$ & $13.1: 1$ \\
\hline
\end{tabular}

cholesterol and cholesterol in HDL, LDL and VLDL, glucose and lipase were determined using a Vitros DT II apparatus (Johnson and Johnson, USA). Hormones were analysed using Coat-A-Count kits (Diagnostic Products Co., USA) for insulin, $\mathrm{T}_{3}$ and $\mathrm{T}_{4}$ and from DPC Diagnostic Poland for leptin.

Statistical analyses were carried out by monofactorial ANOVA using Statgraphics 4.1 Plus. Differences were considered significant at $\mathrm{P}<0.05$. 


\section{RESULTS}

The levels of insulin, leptin, and thyroxin $\left(\mathrm{T}_{4}\right)$ increased significantly and there was a tendency towards increasing $\mathrm{T}_{3}$ in pigs fed the high energy and protein diet (Table 2). The levels of TG and total cholesterol were not significantly different between diets. However, diet L decreased the concentration of HDL cholesterol and increased the concentration of VLDL cholesterol in serum. As expected, the body gain of pigs fed diet $\mathrm{L}$ were lower than on diet $\mathrm{H}$.

Table 2. Level of hormone and lipid metabolism indices in blood serum of pigs fed diets with low $(\mathrm{L})$ or high $(\mathrm{H})$ energy and protein concentrations

\begin{tabular}{lrrcc}
\hline Indices & $\mathrm{L}$ & $\mathrm{H}$ & $\mathrm{SEM}$ & P-value \\
\hline Insulin, $\mathrm{ng} / \mathrm{ml}$ & 5.33 & 10.40 & 2.243 & 0.034 \\
Leptin, ng/ml & 1.75 & 2.62 & 0.345 & 0.003 \\
Cortisol, ug/ml & 7.80 & 9.66 & 1.897 & 0.501 \\
Triiodothyronine, ng/ml & 72.36 & 85.91 & 4.831 & 0.071 \\
Thyroxin, $\mu \mathrm{g} / \mathrm{dl}$ & 4.04 & 5.25 & 0.379 & 0.044 \\
Triacylglycerol, mmol/L & 0.44 & 0.47 & 0.067 & 0.792 \\
Cholesterol total, mmol/L & 2.52 & 2.66 & 0.119 & 0.419 \\
Cholesterol LDL, mmol/L & 0.17 & 0.19 & 0.006 & 0.765 \\
Cholesterol VLDL, mmol/L & 0.06 & 0.05 & 0.082 & 0.019 \\
Cholesterol HDL, mmol/L & 1.01 & 1.21 & 0.0579 & 0.005 \\
Lipase, U/l & 45.16 & 93.28 & 21.536 & 0.157 \\
Glucose, mmol/L & 4.12 & 4.63 & 0.519 & 0.499 \\
Body gain, g/d & 447 & 767 & 0.015 & 0.001 \\
\hline
\end{tabular}

\section{DISCUSSION}

The concentration of insulin in blood serum depends on the intake of dietary energy and protein. A high feeding level increases the insulin concentration in the serum of pigs (Fernandez-Figares et al., 2003). Insulin elevates utilization of glucose for TG synthesis in adipocities and consequently, increases the release of leptin from them. In this investigation, feeding restriction was the reason for decreasing the concentration of insulin and leptin in the serum of pigs.

Da Costa et al. (2004) found that diets with reduced energy and protein contents increased potentials for substrate (protein, glycogen and lipid) turnover and mitochondrial function in growing pigs. This mechanism is probably responsible for sustaining a constant level of glucose and TG despite decreased insulin and leptin concentrations. A decreased level of glucose has often been discussed as an important factor in the anti-aging action of food restriction (Fu at el., 2004). However, it is likely that the amount of glucose available for cell metabolism, but not its serum level, plays a key role in pro-aging activity. Consequently, the 
level of insulin may be an important marker of aging processes. The low level of dietary energy and high level of fibre in diet L did not decrease TG and cholesterol concentrations (total and LDL), but decreased the $\mathrm{T}_{3}, \mathrm{~T}_{4}$ and HDL-cholesterol concentrations in growing pigs. A key role in changing the serum lipid profile is played by the synthesis of apolipoproteins, which can be modified by the concentration of insulin and leptin (Tso et al., 1999).

\section{CONCLUSIONS}

The restriction of energy and protein supply for growing pigs (as a model for young humans) had negative effects on insulin and leptin levels in serum without altering glucose and TG concentrations. The insulin level may be considered a key marker of the pro-aging properties of a diet.

\section{REFERENCES}

Da Costa N., McGillivray C., Bai Q., Wood J.D., Evans G., Chang K.-C., 2004. Restriction of dietary energy and protein induces changes in young porcine skeletal muscles. J. Nutr. 134, 2191-2199

Fernandez-Figares I., Lachica M., Rivera-Ferre M.G., Nieto R., Garcia del Rio C., Aquilera J.F., 2003. Comparative serum metabolites and hormonal profile of Iberian and Landrace growing pigs fed equilibrated or lysine-deficient diets. Proceedings of Symposium EAAP "Progress in Research on Energy and Protein Metabolism”. Rostock (Germany), Publication No. 109

Fu C., Xi L., Wu Y., McCarter R., Richardson A., Hickey M., Han E.-S., 2004. Hepatic genes altered in expression by food restriction are not influenced by the low plasma glucose level in young males GLUT4 trangenic mice. J. Nutr. 134, 2965-2974

Raclot T., Oudart H., 1999. Selectivity of fatty acids on lipid metabolism and gene expression. Proc. Nutr. Soc. 58, 633-646

Tso P., Min Lin, Kologeries T.J., 1999. The role of apolipoprotein AIV in food intake regulation. J. Nutr. 129, 1503-1506

\section{STRESZCZENIE}

\section{Wpływ koncentracji energii w diecie dla świń na profil hormonów i metabolizm lipidów}

Rosnące świnie, jako model badań dla człowieka, $(2$ grupy $\times$ 7) żywiono dietą o wysokiej $(\mathrm{H})$ lub niskiej (L) koncentracji białka i energii. Podawanie dietay L wpłynęło na zmniejszenie poziomu insuliny, leptyny i tyroksyny w krwi; nie uległ zmianie poziom cholesterolu i triacylogliceroli. Zastosowanie diety o niskiej koncentracji energii i białka w żywieniu organizmów rosnących może wpływać na zmniejszenie poziomu kluczowych hormonów anabolicznych. 